\title{
Acute Calcific Retropharyngeal Tendinitis with Eggshell-like Calcification: Case Report and Literature Review on Time-course Changes in Imaging Findings
}

\author{
Norio Yamamoto $^{1}$, Takashi Watari ${ }^{2}$, Keisuke Kawasaki ${ }^{3}$, Yuzuru Matsui ${ }^{1}$, Toshifumi Ozaki ${ }^{4}$ \\ 1. Department of Orthopedic Surgery, Unnan City Hospital, Unnan, JPN 2. Department of Internal Medicine, \\ Postgraduate Clinical Training Center, Shimane University Hospital, Izumo, JPN 3. Department of Orthopedic Surgery, \\ Kagawa Prefectural Central Hospital, Takamatsu, JPN 4. Department of Orthopedic Surgery, Okayama University \\ Graduate School of Medicine, Dentistry and Pharmaceutical Science, Okayama, JPN
}

Corresponding author: Norio Yamamoto, lovescaffe@yahoo.co.jp

\begin{abstract}
Acute calcific retropharyngeal tendinitis is a rare disease, and few studies have reported the radiological findings of its time-course in detail. These radiological findings vary according to the calcific stage. We report a case of acute calcific retropharyngeal tendinitis with eggshell-like calcification detected on followup computed tomography (CT). We also review pertinent literature on calcific retropharyngeal tendinitis, with a focus on time-course changes in imaging findings.
\end{abstract}

A 54-year-old Japanese woman presented with acute severe neck pain. She also had a limited range of motion in the rotation of her neck and moderate pain and discomfort during swallowing. Plain radiographs of the cervical spine showed no apparent abnormality. CT revealed massive retropharyngeal calcification in front of the $\mathrm{C} 1-\mathrm{C} 2$ vertebrae. The patient was diagnosed with acute calcific retropharyngeal tendinitis and treated with a soft collar and non-steroidal anti-inflammatory drugs. Two weeks later, the neck pain and dysphagia improved. At the one-month follow-up, CT showed residual marginal calcification, which was diminishing in size, suggesting eggshell-like calcification.

We believe that although the eggshell calcification appearance is extremely rare, it is important to note this atypical presentation of acute calcific retropharyngeal tendinitis.

Received 03/21/2020

Review began 03/24/2020

Review ended 04/07/2020

Published 04/10/2020

๑) Copyright 2020

Yamamoto et al. This is an open access article distributed under the terms of the Creative Commons Attribution License CC-BY 4.0., which permits unrestricted use, distribution, and reproduction in any medium, provided the original author and source are credited.
Categories: Emergency Medicine, Radiology, Orthopedics

Keywords: acute calcific retropharyngeal tendinitis, acute calcific tendonitis of the longus colli, eggshell calcification, time-course changes

\section{Introduction}

Acute calcific retropharyngeal tendinitis is a reactive, self-limiting inflammatory response to the acute deposition of calcium hydroxyapatite crystals in the tendons of the longus colli muscle at the anterior C1-C2 [1]. It is a rare disease, which is probably underdiagnosed because physicians are often unfamiliar with its presentation; further, it has a self-limiting pathology [2]. Although previous studies have described the radiological presentation on diagnosis, only a few reports have provided the radiological findings of its time-course in detail [3]. This disease is thought to be a self-limiting condition that resolves spontaneously after one to two weeks. Although symptoms are not always synchronous with their radiological findings, one to two months may be needed for complete healing on the basis of the literature review [3].

Herein, we report a case of acute calcific retropharyngeal tendinitis with eggshell calcification, which was detected on follow-up computed tomography (CT). We also review the pertinent literature on calcific retropharyngeal tendinitis, with a focus on time-course changes in imaging findings.

\section{Case Presentation}

Table 1 shows our review of the literature. 


\section{Cureus}

\begin{tabular}{|c|c|c|c|c|}
\hline Authors & $\begin{array}{l}\text { Age } \\
\text { (years) / } \\
\text { Sex }\end{array}$ & $\begin{array}{l}\mathrm{F} / \mathrm{U} \text { image and } \\
\text { period }\end{array}$ & F/U image findings & $\begin{array}{l}\text { Symptomatic } \\
\text { resolution }\end{array}$ \\
\hline $\begin{array}{l}\text { Tezuka et } \\
\text { al. [3] }\end{array}$ & $59 / \mathrm{F}$ & $\begin{array}{l}\text { CT, } 3 \text { weeks; } \\
\text { MRI, } 6 \text { months }\end{array}$ & $\begin{array}{l}\text { CT: almost complete disappearance of the amorphous calcification. } \\
\text { MRI: no fluid in the retropharyngeal space. }\end{array}$ & Two weeks \\
\hline $\begin{array}{l}\text { Tamm et } \\
\text { al. [4] }\end{array}$ & $41 / \mathrm{F}$ & CT, 2 months & $\begin{array}{l}\text { Resolution of the effusion and near-complete resolution of the } \\
\text { calcification. }\end{array}$ & Three months \\
\hline $\begin{array}{l}\text { Tagashira } \\
\text { et al. [5] }\end{array}$ & $40 / \mathrm{M}$ & CT, 3 months & The calcification had disappeared. & Three days \\
\hline $\begin{array}{l}\text { Estimable } \\
\text { et al. [6] }\end{array}$ & $45 / \mathrm{M}$ & MRI, 7 weeks & $\begin{array}{l}\text { Improvement in the prevertebral non-enhancing walled fluid } \\
\text { collection. }\end{array}$ & One week \\
\hline Oh et al. [7] & $25 / \mathrm{M}$ & $\begin{array}{l}\text { Radiograph, } 2 \\
\text { months }\end{array}$ & The prevertebral swelling markedly improved. & Two months \\
\hline $\begin{array}{l}\text { Kim et al. } \\
{[8]}\end{array}$ & $41 / \mathrm{F}$ & CT, 1 week & $\begin{array}{l}\text { Decrease in the calcific deposit and retropharyngeal soft tissue } \\
\text { swelling. }\end{array}$ & Ten days \\
\hline $\begin{array}{l}\text { Narváez et } \\
\text { al. [9] }\end{array}$ & $47 / \mathrm{F}$ & CT, 5 months & Calcification and soft tissue swelling had disappeared. & Three months \\
\hline $\begin{array}{l}\text { Matsuura } \\
\text { et al. [10] }\end{array}$ & $44 / \mathrm{M}$ & CT, 3 months & Calcification and soft tissue swelling had disappeared. & Four days \\
\hline $\begin{array}{l}\text { Present } \\
\text { case }\end{array}$ & $54 / F$ & CT, one month & Residual marginal calcification, decreasing in size. & Two weeks \\
\hline
\end{tabular}

\section{TABLE 1: Review of the literature on acute calcific retropharyngeal tendinitis with a focus on the time-course changes in the imaging finding}

F, female; M, male; F/U, follow-up; CT, computed tomography; MRI, magnetic resonance imaging

A 54-year-old Japanese woman presented with acute severe neck pain. The pain was of acute onset and had started 12 hours prior to her hospital visit. She had no significant medical history. Her vital signs were normal, with the exception of mild fever $\left(37.5^{\circ} \mathrm{C}\right)$. She also had a limited range of motion during rotation of her neck and moderate pain and discomfort during swallowing. She had no oropharyngeal abnormalities, meningeal signs, and neurological abnormalities.

Laboratory data showed a slight elevation of C-reactive protein (0.29), an erythrocyte sedimentation rate of $16 \mathrm{~mm} / \mathrm{h}$, and a normal white blood cell count (4100/ul). Other laboratory findings were within normal limits. Plain radiographs of the cervical spine showed no apparent abnormality (Figure 1). Owing to suspicion of emergent diseases, such as a retropharyngeal abscess, CT of the neck was performed. It revealed massive retropharyngeal calcification with its longest diameter $(18 \mathrm{~mm})$ in front of the $\mathrm{C} 1-\mathrm{C} 2$ vertebrae (Figure 2). It was inhomogeneous and irregularly shaped with associated soft tissue swelling. Magnetic resonance imaging (MRI) showed markedly increased signal intensity on T2-weighted images and intermediate signal intensity on T1-weighted images at the anterior C1 to C5 level (Figure 3). There were no findings of spondylitis, epidural abscess, or tumor. 


\section{Cureus}

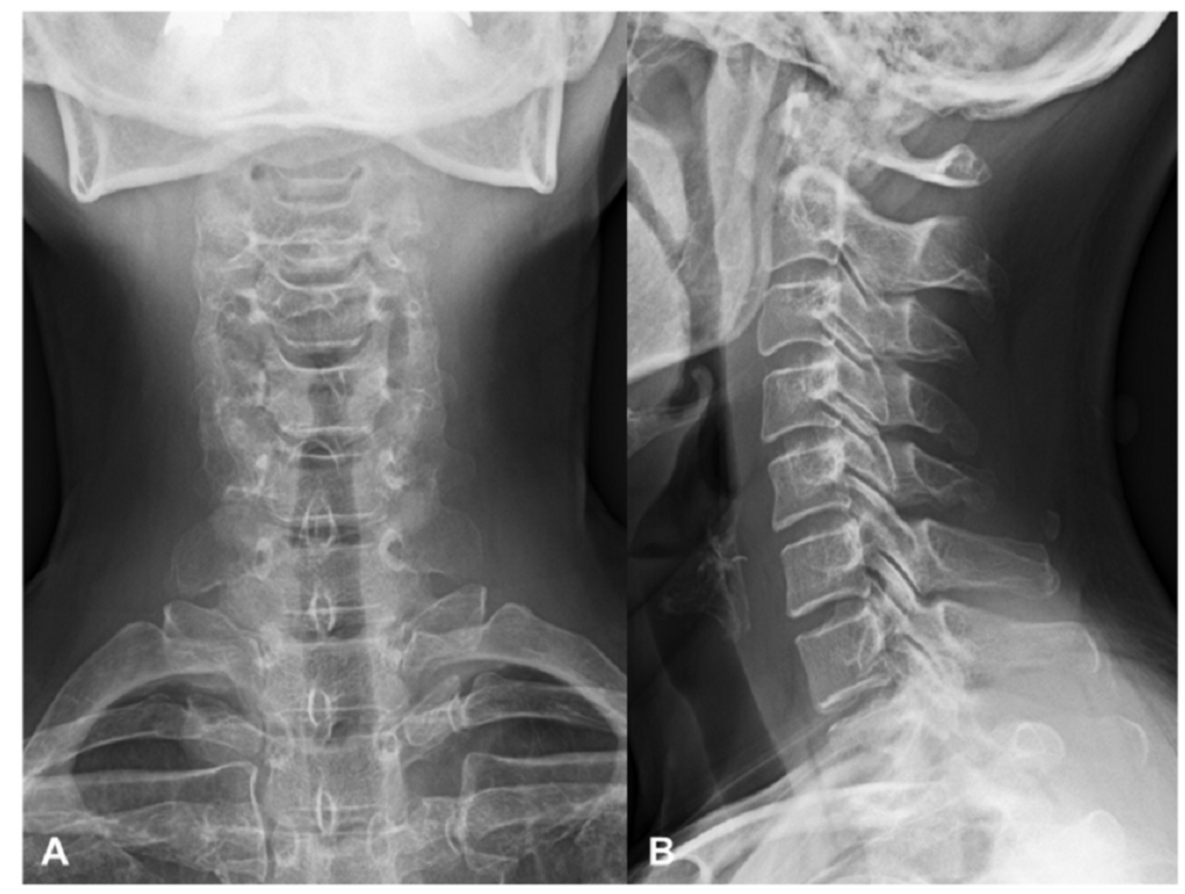

FIGURE 1: Plain radiographs of the cervical spine on initial presentation Anteroposterior $(\mathrm{A})$ and lateral $(\mathrm{B})$ radiographs showing no apparent abnormality

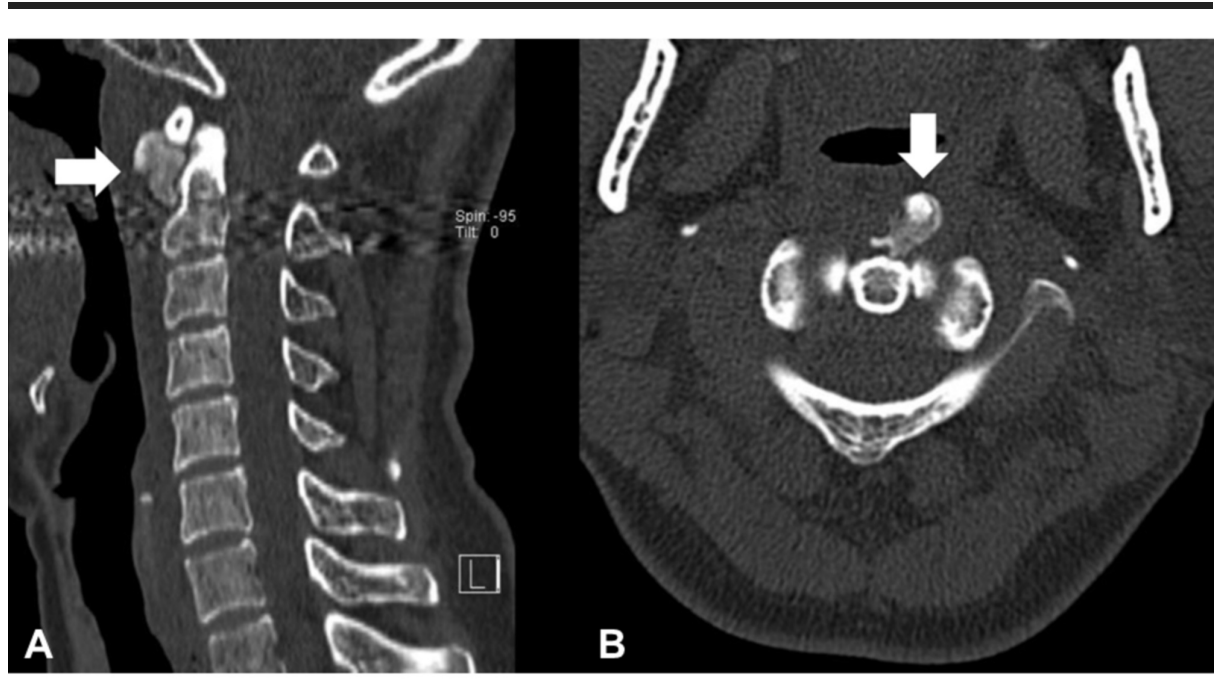

FIGURE 2: Non-contrast computed tomography (CT) scans of the cervical spine on initial presentation

(A) Sagittal and (B) Axial CT scan (bone window) demonstrating amorphous calcification anterior to the C1 and C2 levels with the associated soft tissue swelling (arrows) 


\section{Cureus}

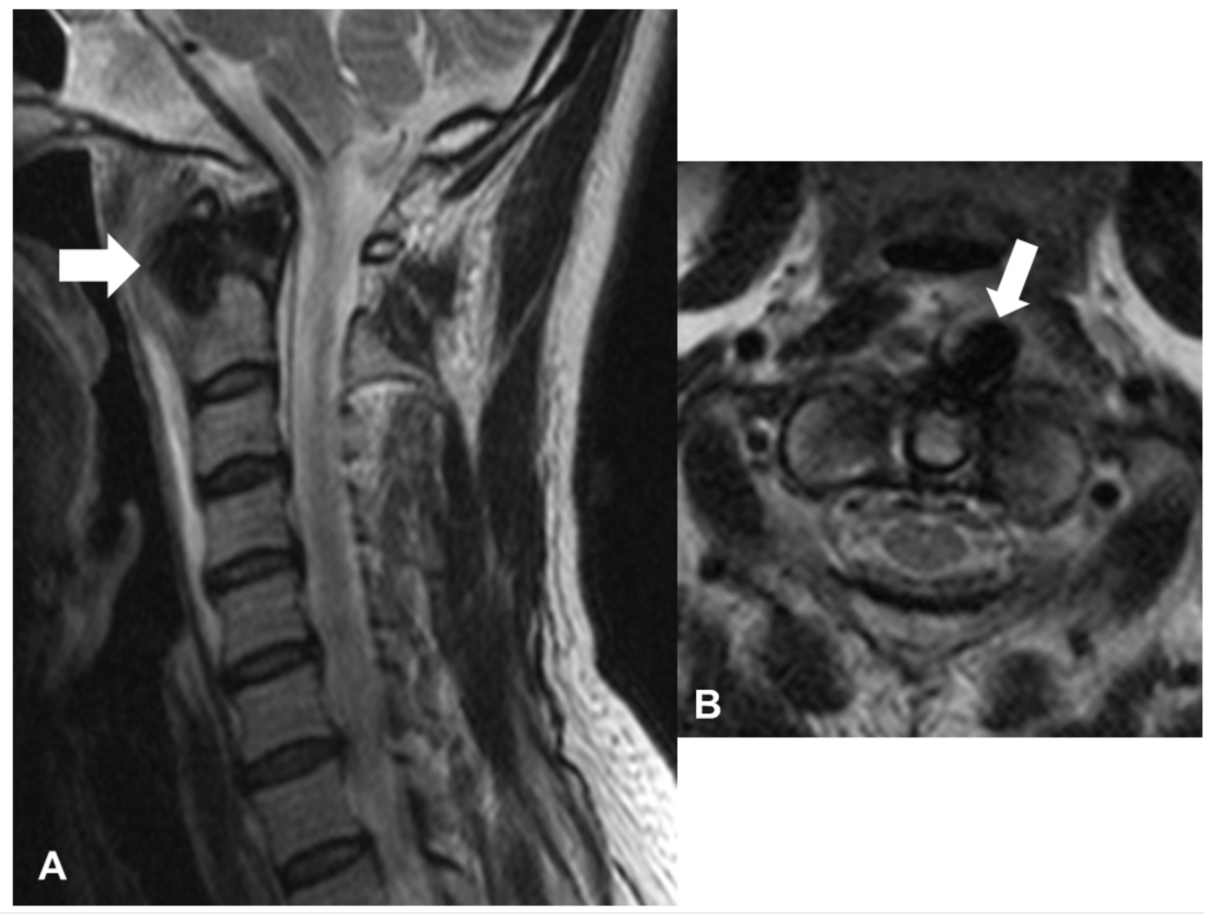

\section{FIGURE 3: Magnetic resonance imaging of the cervical spine on initial}

presentation

(A) Sagittal and (B) Axial T2-weighted images showing increased signal intensity in the retropharyngeal space between $\mathrm{C} 1$ and $\mathrm{C} 5$ (arrows)

Thus, the patient was diagnosed with acute calcific retropharyngeal tendinitis, and the condition was treated with a soft collar and non-steroidal anti-inflammatory drugs (NSAIDs). Two weeks later, the neck pain and dysphagia improved. At the one-month follow-up, she had a complete resolution of the symptoms. A followup CT showed residual marginal calcification, which was diminishing in size, suggesting an eggshell-like calcification (Figure 4).

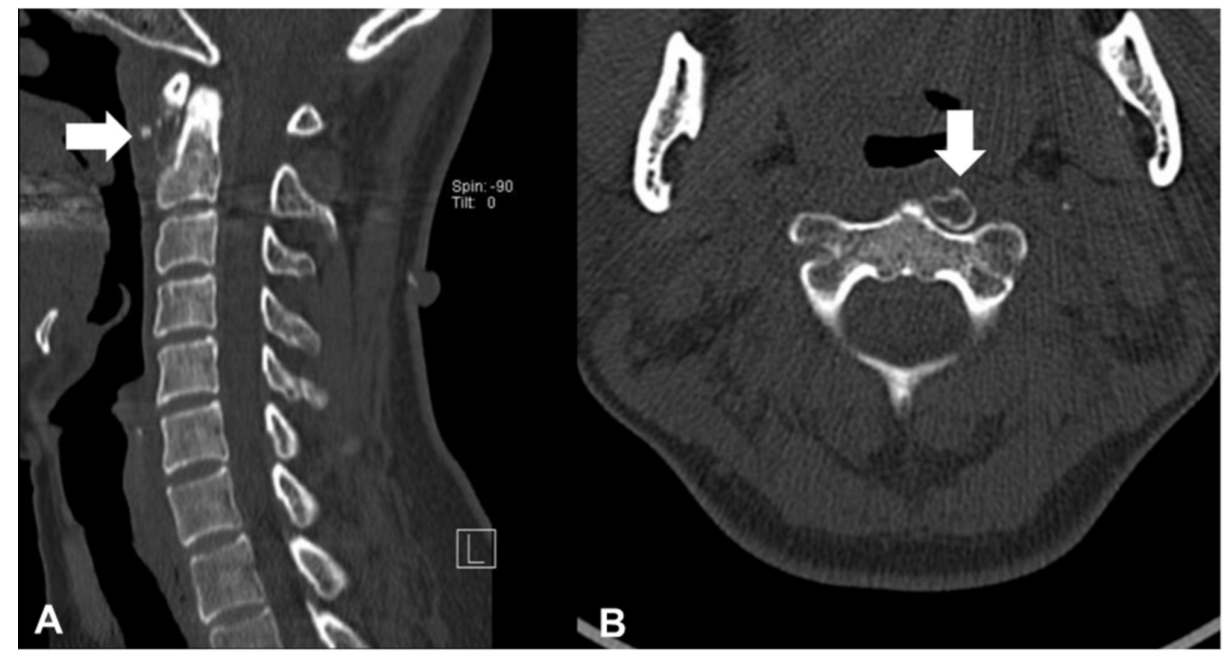

FIGURE 4: Computed tomography (CT) scans of the cervical spine at the one-month follow-up

(A) Sagittal and (B) Axial CT showing marginal calcification, suggesting an eggshell-like calcification with reduced soft tissue swelling (arrows)

\section{Discussion}


To our knowledge, this is the first report of acute calcific retropharyngeal tendinitis with eggshell calcification detected on follow-up CT. A few cases on acute calcific retropharyngeal tendinitis, including the time-course changes in the imaging findings, have been reported (Table 1) [3-10]. All cases in the literature review showed symptomatic resolution and improvement of the acute calcific retropharyngeal inflammation on consecutive images, although the previous studies reported that it was a self-limiting disease without follow-up imaging findings. Residual marginal calcification was only reported in our case. We speculate that the time-course differences in imaging findings may be attributed to the degree of inflammation and the intervals at which consecutive images were obtained.

The pathogenesis of the calcium deposition was suspected to be related to trauma, repetitive ischemia, and degeneration. The natural history of acute calcific retropharyngeal tendinitis according to image findings remains unclear. Calcific tendinitis has the following three time-course stages: pre-calcification, calcific, and post-calcific [11]. During the resorptive phase of the calcific stage, calcific deposits are invaded by macrophages, polymorphonuclear cells, and fibroblasts. This is the most painful phase of calcific tendonitis, and the calcium deposits have a toothpaste-like appearance. Subsequently, the post-calcific stage is characterized by granulation tissue formation, which replaces the space that was previously occupied by the calcium deposits [11]. A previous report on the radiologic course of acute symptomatic calcific tendinopathy of the shoulder indicated that $46 \%$ of the calcific deposits tended to become cloudier and more inhomogeneous than the initial findings, and $62 \%$ of cases presented with complete resolution or decrease in size [12]. In the present case, we speculated that the eggshell calcification phenomenon might be a marginal deposit at the post-calcific stage, although symptoms are not synchronous with the radiological findings.

The time required for complete absorption of the calcium deposits was about one month [3]. In the clinical setting, when the CT finding of a patient with neck pain shows eggshell calcification, clinicians should suspect calcific retropharyngeal tendinitis at the post-calcific stage and should avoid unnecessary interventions. The differential diagnosis of eggshell calcification includes esophageal schwannoma, thyroid tumor, retropharyngeal abscess, lymph node calcification, heterotopic ossification, and ossifying myositis [13-14].

\section{Conclusions}

The radiological findings of the time-course of acute calcific retropharyngeal tendinitis show different findings according to the calcific stage. Although the eggshell-like calcification appearance is extremely rare, it is important to note this atypical presentation of acute calcific retropharyngeal tendinitis.

\section{Additional Information \\ Disclosures}

Human subjects: Consent was obtained by all participants in this study. Unnan City Hospital IRB issued approval 20190022. Conflicts of interest: In compliance with the ICMJE uniform disclosure form, all authors declare the following: Payment/services info: All authors have declared that no financial support was received from any organization for the submitted work. Financial relationships: All authors have declared that they have no financial relationships at present or within the previous three years with any organizations that might have an interest in the submitted work. Other relationships: All authors have declared that there are no other relationships or activities that could appear to have influenced the submitted work.

\section{References}

1. Ring D, Vaccaro AR, Scuderi G, Pathria MN, Garfin SR: Acute calcific retropharyngeal tendinitis. Clinical presentation and pathological characterization. J Bone Joint Surg Am. 1994, 76:1636-1642. 10.2106/00004623-199411000-00006

2. Horowitz G, Ben-Ari O, Brenner A, Fliss DM, Wasserzug O: Incidence of retropharyngeal calcific tendinitis (longus colli tendinitis) in the general population. Otolaryngol Head Neck Surg. 2013, 148:955-958. 10.1177\%2F0194599813482289

3. Tezuka F, Sakai T, Miyagi R, et al.: Complete resolution of a case of calcific tendinitis of the longus colli with conservative treatment. Asian Spine J. 2014, 8:675-679. 10.4184\%2Fasj.2014.8.5.675

4. Tamm A, Jeffery CC, Ansari K, Naik S: Acute prevertebral calcific tendinitis. J Radiol Case Rep. 2015, 9:1-5. 10.3941/jrcr.v9i11.2494

5. Tagashira Y, Watanuki S: Acute calcific retropharyngeal tendonitis . CMAJ. 2015, 187:995. 10.1503/cmaj.140214

6. Estimable K, Rizk C, Pujalte GGA: A rare case of neck pain: acute longus colli calcific tendinitis in a possibly immunocompromised individual. J Am Board Fam Med. 2015, 28:146-150. 10.3122/jabfm.2015.01.140124

7. Oh JY, Lim JH, Kim YS, Kwon YE, Yu JY, Lee JH: Misconceived retropharyngeal calcific tendinitis during management of myofascial neck pain syndrome. Korean J Pain. 2016, 29:48-52. 10.3344/kjp.2016.29.1.48

8. Kim YJ, Park JY, Choi KY, Moon BJ, Lee JK: Case reports about an overlooked cause of neck pain. Calcific tendinitis of the longus colli. Case reports. Medicine. 2017, 96:e8343. 10.1097/MD.0000000000008343

9. Narváez J, Morales-Ivorra I, Martínez-Yelamos S, Narváez JA: Acute calcific tendinitis of the longus colli muscle. Am J Med. 2018, 131:365-366. 10.1016/j.amjmed.2018.04.017 


\section{Cureus}

10. Matsuura H, Sugimoto Y, Sasaki E, Kiura Y, Kishida M: Acute calcific retropharyngeal tendinitis. Postgrad Med J. 2019, 95:678. 10.1136/postgradmedj-2019-136750

11. Kachewar SG, Kulkarni DS: Calcific tendinitis of the rotator cuff: a review . J Clin Diagn Res. 2013, 7:14821485. 10.7860/JCDR/2013/4473.3180

12. Cho NS, Lee BG, Rhee YG: Radiologic course of the calcific deposits in calcific tendinitis of the shoulder: does the initial radiologic aspect affect the final results?. J Shoulder Elbow Surg. 2010, 19:267-272. 10.1016/j.jse.2009.07.008

13. Ahn D, Sohn JH, Kim H, Yeo CK: Large esophageal schwannoma mimicking thyroid tumor with egg-shell calcification on preoperative ultrasonography. Asian J Surg. 2017, 40:236-239. 10.1016/j.asjsur.2014.04.002

14. Beckmann NM: Calcium apatite deposition disease: diagnosis and treatment. Radiol Res Pract. 2016, 2016:4801474. 10.1155/2016/4801474 